\title{
The Microanatomy and Ecology of 'Chlorochromatium aggregatum' in Two Meromictic Lakes in Tasmania
}

\author{
By ROGER L. CROOME AND PETER A. TYLER* \\ Department of Botany, University of Tasmania, Box 252C, GPO, Hobart, Tasmania 7001. \\ Australia
}

(Received 9 March 1984; revised 24 May 1984)

\begin{abstract}
The motile ectosymbiotic consortium 'Chlorochromatium aggregatum' occurs in large numbers in two meromictic lakes in Tasmania. In its structure it resembles specimens previously described, except that vesicles or mesosomes are present in the central bacterium. The population occupies a narrow stratum near the chemocline, but may occur either above or below it, in microaerobic or anaerobic conditions, respectively. Its presence under aerobic conditions need not invalidate previous hypotheses concerning the mutualistic relationship between the two partners of the consortium.
\end{abstract}

\section{INTRODUCTION}

Several bacterial consortia have been described in which a central, chemoorganotrophic, motile bacterium is covered by synchronously dividing sulphur bacteria (Trüper \& Pfennig, 1978). The Chlorobiaceae are the only bacteria known to form such ectosymbiotic associations. The consortia were originally described as species. However, this is "without standing in nomenclature' (Trüper \& Pfennig, 1971). The names are still useful, however, and are freely used in the literature; where they appear here they are placed in inverted commas.

The best example of such consortia is 'Chlorochromatium aggregatum' Lauterborn, in which cells of green sulphur bacteria are regularly arranged around a large, colourless, polarly flagellated, rod-shaped bacterium of unknown physiological activity and taxonomic position (Stanier et al., 1981). There is little doubt that the green bacteria belong to the genus Chlorobium (Trüper \& Pfennig, 1971). Growth and division of all cells occur synchronously, indicating a high degree of metabolic interdependence.

Stanier et al. (1971) and Gorlenko et al. (1977) have published light micrographs of ${ }^{\circ} C$. aggregatum' and Caldwell \& Tiedje (1975) have published electron micrographs of ultrathin sections. Pfennig (1980) has discussed it in a review article of syntrophic mixed cultures and symbiotic consortia. In the latter work, the hypothesis is presented that the central bacterium is either a sulphate- or sulphur-reducing bacterium. However, repeated attempts at culturing the central bacterium in isolation have failed. One possible reason for this is that the central bacterium of the consortium functions as an electron donor, and is obligately dependent on the green sulphur bacteria as electron acceptors: growth of the central bacterium in pure culture would therefore be impossible (Pfennig, 1980).

'Chlorochromatium aggregatum' and other, less known consortia (see Starr \& Schmidt, 1981) exhibit chemo- and phototactic responses and accumulate in conditions of optimum sulphide concentrations and light intensity (Pfennig, 1978). They have been found only in freshwater habitats, and may occur both in shallow pools above the mud and in the layers of green or purple sulphur bacteria in stratified lakes.

'Chlorochromatium aggregatum' occurs in two dystrophic, meromictic lakes in the south-west wilderness area of Tasmania, Australia. The two lakes, Lake Fidler and Sulphide Pool, both have severe physico-chemical stratification at a depth of 2-3 m, with a finely structured microbial array across this chemocline. The general features of the lakes and their micro- 
organisms have been described elsewhere (King \& Tyler, 1981, 1982, 1983; Croome \& Tyler, $1983 a, b, 1984)$. 'Chlorochromatium aggregatum' is a prominent member of the stratified microbial community in both lakes, occurring at dimly lit depths in the vicinity of the chemocline. Here, we describe its microanatomy and ecology in these meromictic lakes.

\section{METHODS}

Most of the field and analytical methods have been published in previous descriptions of the lakes (e.g. King \& Tyler, 1981; Croome \& Tyler, 1984). The physico-chemical zonation and accompanying microbial array was sampled with a close-interval pneumatic sampler (Croome \& Tyler, 1984). Specimens for scanning electron microscopy were exposed to $1 \%$ osmium tetroxide vapour for $20-30 \mathrm{~s}$, placed on polylysine-coated glass coverslips (Marchant \& Thomas, 1983), dehydrated in an acetone series, critical point dried using $\mathrm{CO}_{2}$ as the intermediary fluid, sputter coated with gold, and viewed using a Philips 505 scanning electron microscope. Material for ultrathin sectioning was concentrated by centrifugation, fixed in $1 \%$ glutaraldehyde and $1 \%$ osmium tetroxide, dehydrated in acetone, and embedded in Spurr's resin. After sectioning, the material was placed on Formvarcoated copper grids, stained with $1 \%$ uranyl acetate and Reynold's lead citrate, and viewed using an Hitachi $\mathrm{H}-300$ transmission electron microscope.

\section{RESULTS}

Light micrographs and scanning electron micrographs of the consortium are shown in Fig. 1. By light microscopy there is no perceptible difference between consortia from the two lakes. The consortium appears as a slightly knobbly, square to rectangular shape (Fig. $1 a, b$ ), grey under phase contrast microscopy, which slowly revolves about its long axis as it swims along an undulating path. Recently divided consortia are approximately cubical, about $2 \mu \mathrm{m}$ long by $1.5 \mu \mathrm{m}$ wide. Dividing consortia are more elongate. Scanning electron microscopy shows that in non-dividing consortia the outer, phototrophic bacteria are arranged more or less at right angles to the long axis (Fig. 1 c), though in elongate, dividing consortia some cells may be randomly orientated (Fig. le) or almost longitudinally arranged (Fig. 1d). Although the consortia are motile, we have never seen flagella by either light or electron microscopy.

By transmission electron microscopy (Fig. 2) the internal structure of the green phototrophic bacteria of the outer layer is similar to that of the free-living Chlorobium populations in the lakes (see below). The cells are of the Chlorobium limicola type and the characteristic chlorobium vesicles are quite apparent.

The central bacterium is comparatively long, occasionally exceeding $3 \mu \mathrm{m}$ in length, and of the order of $0.5-1.0 \mu \mathrm{m}$ in diameter. The cell wall is often in close contact with those of the phototrophic bacterial cells around it, and displays structures similar to those described by Caldwell \& Tiedje (1975) as hexagonal cups, postulated to play a role in maintaining the integrity of the consortium (Fig. 2a,b). The matrix of the central bacterium is lacking in detail, but large vesicles or mesosomes were observed near the cell wall (Fig. $2 c, d$ ). Such structures have not been reported previously for the central bacterium, and their function is unknown.

Lake Fidler and Sulphide Pool display abrupt changes in physical and chemical conditions across the chemocline, typical of meromictic lakes. Seasonal variation in these conditions has been described by King \& Tyler $(1982,1983)$. Fig. 3 shows a typical example, from Lake Fidler, of this physico-chemical zonation and of the accompanying microbial array. The sharpness of the chemocline is best demonstrated by the almost horizontal redoxcline, above which there is usually a microaerobic zone. The microbial array consists of the flagellates Trachelomonas volvocina Ehrenb. and Scourfieldia caeca (Korsh.) Belcher et Swale, the colourless sulphur bacteria cf. Achromatium and Beggiatoa, the free-living phototrophic bacterium Chlorobium, and 'Chlorochromatium aggregatum'. All of these except ' $C$. aggregatum' maintain a more or less constant position, relative to the chemocline, diurnally and throughout the year; $C$. aggregatum', on the other hand, varies its position from high in the microaerobic zone $(0.25 \mathrm{~m}$ above the redoxcline), at an oxygen concentration of $0.4 \mathrm{mg} \mathrm{l}^{-1}$ and a redox potential of +350 $\mathrm{mV}$, to well within the anaerobic zone, with a sulphide concentration of $30 \mathrm{mg}^{-1}$ and redox of 

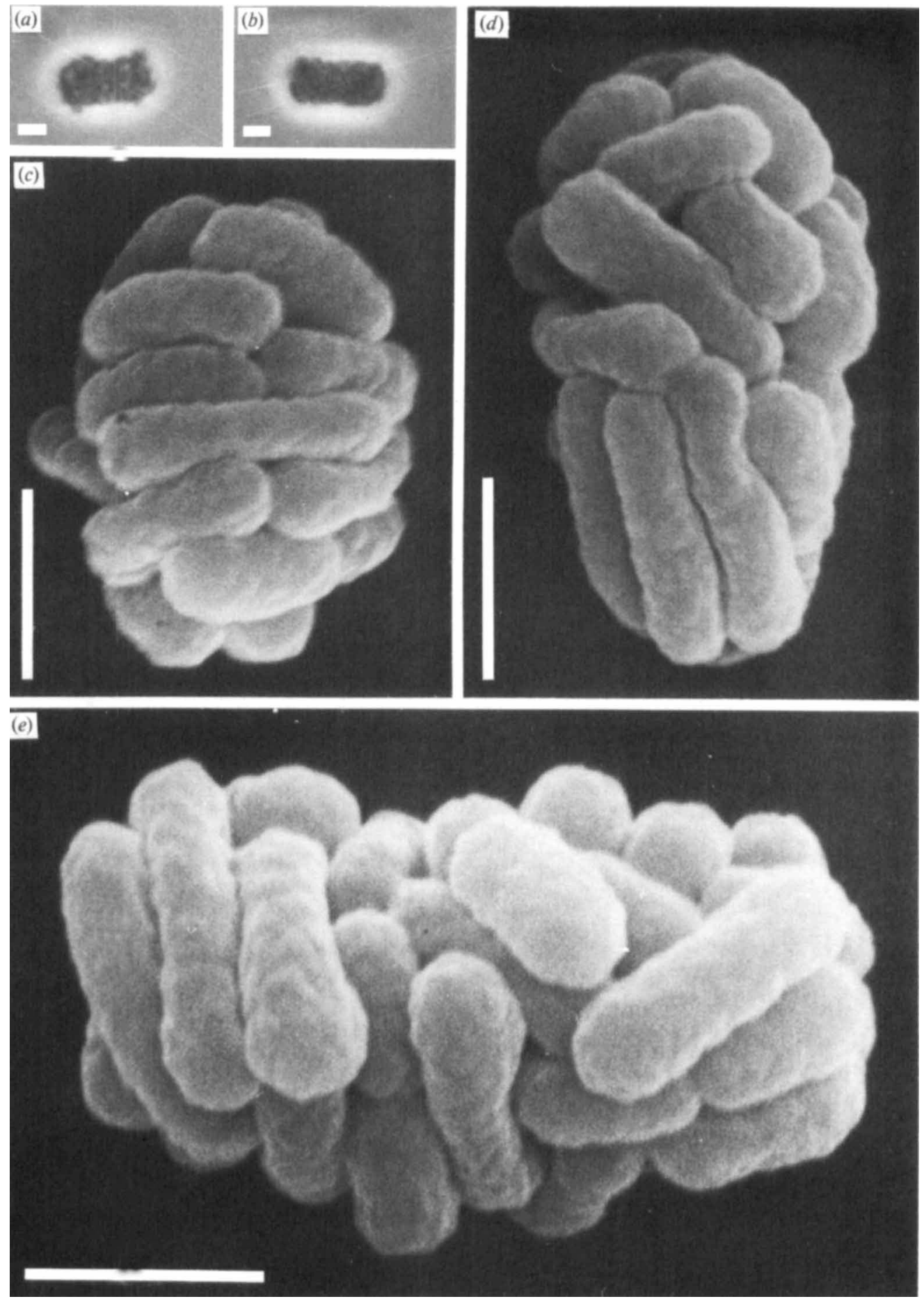

Fig. 1. Whole mounts of 'Chlorochromatium aggregatum' . $(a, b)$ Light micrographs of live, dividing consortia. $(c, d, e)$ Scanning electron micrographs of single and dividing consortia. Bars represent $1 \mu \mathrm{m}$. 

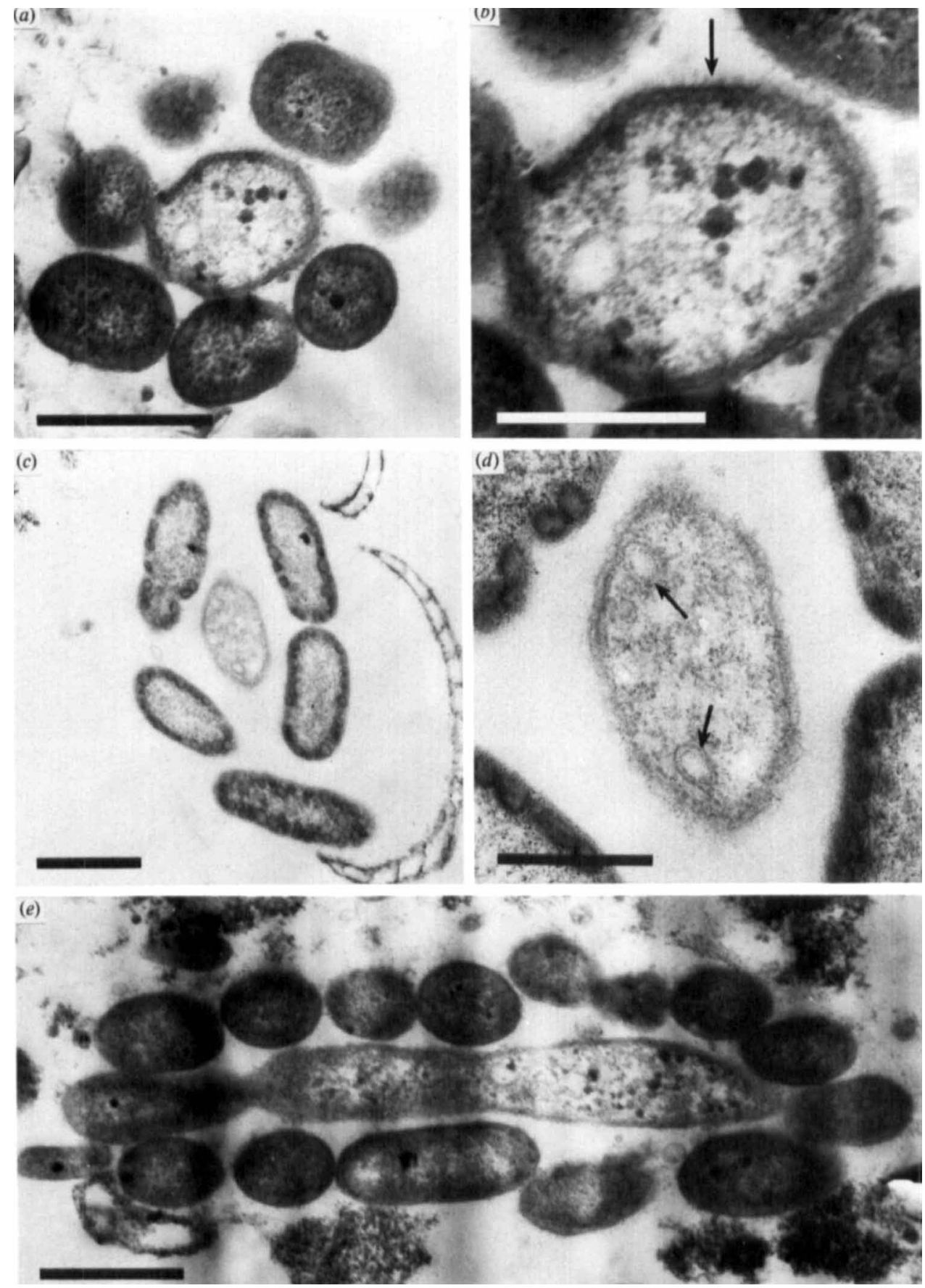

Fig. 2. Ultrathin sections of 'Chlorochromatium aggregatum'. (a) Transverse section of a consortium; bar, I $\mu \mathrm{m}$. (b) Central bacterium enlarged to show surface structures (arrow): bar, $0.5 \mu \mathrm{m}$. (c) Oblique section of a consortium; bar, $1 \mu \mathrm{m}$. (d) Central bacterium enlarged to show vesicles or mesosomes (arrows); bar, $0.5 \mu \mathrm{m}$. (e) Longitudinal section of a dividing consortium; bar, $1 \mu \mathrm{m}$. 


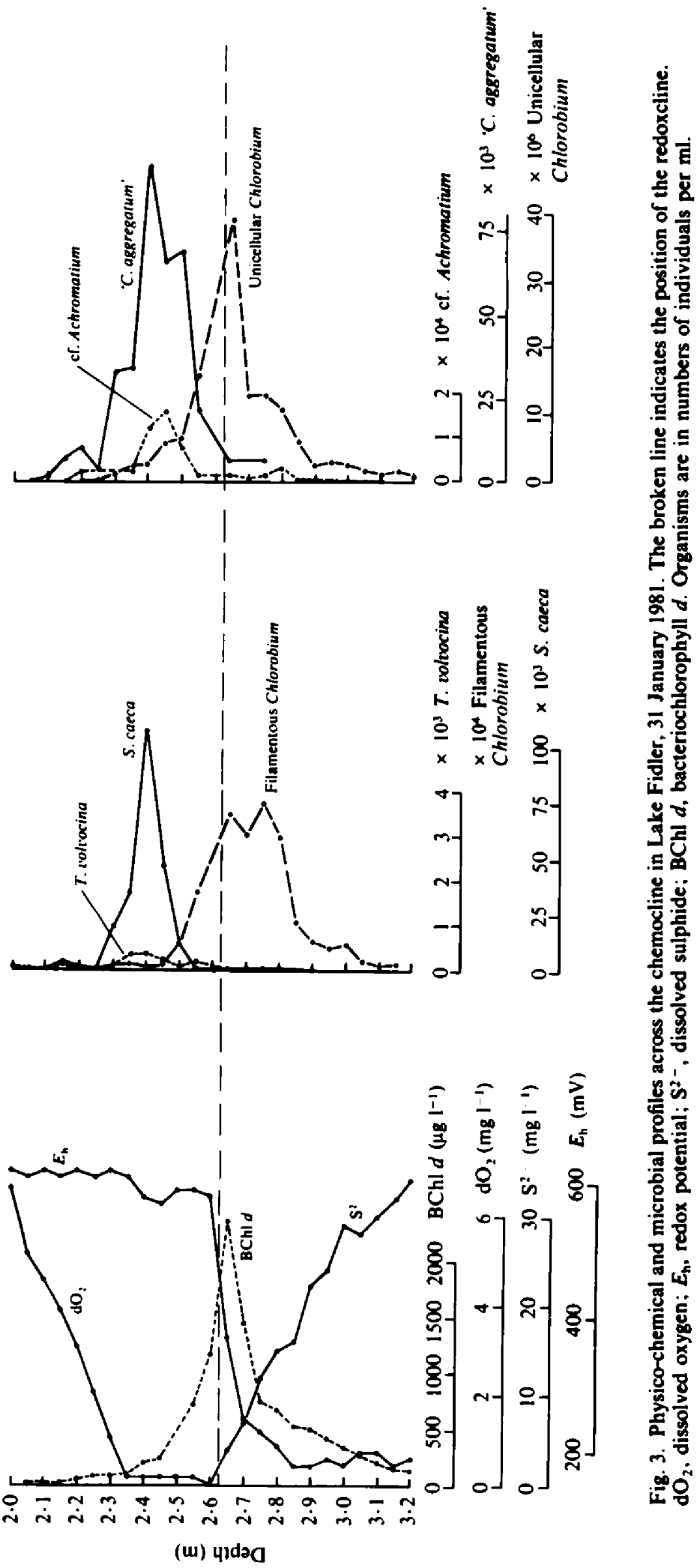


$-100 \mathrm{mV}$. Between January 1981 and April 1983 numbers ranged from $10^{2}$ to $64 \times 10^{4}$ consortia per $\mathrm{ml}$ at the depth of the population peak, usually occupying a layer about $0.1 \mathrm{~m}$ thick. Because the population of ' $\mathrm{C}$. aggregatum' was usually outnumbered by that of Chlorobium in the same stratum, a discrete bacteriochlorophyll peak attributable to the consortium could not be discerned.

Though the position of the chemocline relative to lake surface varies with water level it is always at such a depth that light is severely attenuated and restricted to wavelengths $>550 \mathrm{~nm}$ by the dystrophic water (King \& Tyler, 1982; Croome \& Tyler, 1984). The population of ' $C$. aggregatum' always receives much less than $1 \%$ of surface photosynthetically-active radiation.

'Chlorochromatium aggregatum' also occurs in Sulphide Pool but it was not observed there before April 1982. It occurs there under similar environmental conditions and occupies the same niche as in Lake Fidler. It is possible that it was introduced to Sulphide Pool by sampling equipment previously used in Lake Fidler.

\section{DISCUSSION}

The structure of ' $C$. aggregatum' from Lake Fidler is similar to that found by previous workers, with cells of Chlorobium enveloping and being in close contact with a large central bacterium. It is also similar in its ultrastructure, the phototrophic symbionts possessing distinct chlorobium vesicles, and the central bacterium being surrounded by structures which may help to keep the consortium together (Caldwell \& Tiedje, 1975). The vesicles or mesosomes observed in the central bacterium have not been reported previously, and their function is unknown.

The consortium ' $C$. aggregatum' has been found in large numbers in several other stratified lakes. In Lake Sakovo (Gorlenko \& Chebotarev, 1981) and Lesnaya Lamba, Karelia, USSR (Dubinina \& Kuznetsov, 1976) it occurred at the same depth as free-living green phototrophic bacteria, in numbers up to 420000 and 100000 consortia $\mathrm{ml}^{-1}$, respectively. In Lake Nesoytjern, Norway, it was recorded at 30000 consortia ml-1 (Blakar, 1979), and in Burke Lake, Mich., USA, it comprised $10 \%$ of the phototrophic bacterial community (Caldwell \& Tiedje, 1975). It has also been reported in Lakes Mary and Rose, Wis., USA (Parkin \& Brock, 1980) and in Estonian lakes (Gorlenko \& Lokk, 1979). In all cases, it has been reported as inhabiting strictly anaerobic regions.

In Lake Fidler, where concentrations of ' $C$. aggregatum' up to 640000 consortia $\mathrm{ml}^{-1}$ have been recorded, the largest population maximum yet reported for this 'organism', it has been found under both aerobic and anaerobic conditions. This is interesting in the light of the recent hypothesis (Pfennig, 1980) as to the relationship between the two members of the consortium, that the central organism is a sulphate- or sulphur-reducing bacterium utilizing extracellular sulphur produced by the phototrophic bacteria, which in turn use dissolved sulphide, produced by the central bacterium, as an electron donor for their anoxygenic photosynthesis. At the same time the Chlorobium cells gain motility, enabling positive phototactic responses. The presence of 'C. aggregatum' in the microaerobic zone of Lake Fidler in no way negates this hypothesis, but enhances it. When present in the anoxic zone the metabolic activity of the consortium could be just as supposed above. Its presence in the microaerobic zone most probably results from a positive phototactic response, and although the reducing conditions required for anaerobic photosynthesis would not be present outside the consortium, they could well prevail between the cells within it. Why ' $C$. aggregatum' should be found high in the microaerophilic zone in one month, and well into the sulphide zone in another, is not known. Its location is presumably a response to light, redox potential, nutrients and sulphur distribution. We presume (Croome \& Tyler, 1984) that the presence of viable cells of the other phototrophic constituent of the microbial array, free-living Chlorobium, above the redoxcline under microaerobic conditions indicates inefficient depth regulation by some members of the population.

We thank the Australian Research Grants Scheme and the University of Tasmania for research grants. We thank sincerely Dr H. J. Marchant and Mr R. Cruikshank for assistance with specimen preparation, and Dr D. P. Thomas and $\mathrm{Mr}$ A. Eastgate for assistance during electron microscopy. 


\section{REFERENCES}

Blakar, I. A. (1979). A close-interval water sampler with minimal disturbance properties. Limnology and Oceanography 24, 983-988.

Caldwell, D. E. \& Tiedje, J. M. (1975). The structure of anaerobic bacterial communities in the hypolimnion of several Michigan lakes. Canadian Journal of Microbiology 21, 377-385.

CROOME, R. L. \& TYLER, P. A. (1983a). Mallomonopsis tasmantica sp. nov. (Chrysophyceae) and Mallomonopsis elliptica Matvienko from Australia. British Phycological Journal 18, 357-365.

Croome, R. L. \& TyLer, P. A. (1983b). Mallomonas morrisonensis (Chrysophyceae) a new species from Australia. British Phycological Journal 18, 383-389.

Croome, R. L. \& Tyler, P. A. (1984). Microbial microstratification and crepuscular photosynthesis in meromictic Tasmanian lakes. Verhandlungen der internationalen Vereinigung für theoretische und angewandte Limnologie 22 (in the Press)

Dubinina, G. A. \& Kuznetsov, S. I. (1976). The ecological and morphological characteristics of microorganisms in Lesnaya Lamba (Karelia). Imternationale Retue der gesamten Hydrobiologie 61, 1 - 19.

Gorlenko, V. M. \& Chebotarev, E. N. (1981). Microbiological processes in the meromictic Lake Sakovo. Microbiology' (English translation of Mikrobiologiya) 50, 98-102.

GoRlenko, V. M. \& LOKK. S. I. (1979). Vertical distribution and species composition of microorganisms from some stratified Estonian lakes. Microbiology (English transiation of Mikrobiologiya) 48. 283-290.

Gorlenko, V. M., Dubinina, G. A. \& Kuznetsov, C. I. (1977). The Ecology of Aquatic Microorganisms. Moscow: Academy of Sciences of the USSR.

KING, R. D. \& TYLER, P. A. (1981). Meromictic lakes of south-west Tasmania. Australian Journal of $\mathrm{Ma}$ rine and Freshwater Research 32, 741-756.

King, R. D. \& TYleR, P. A. (1982). Lake Fidler, a meromictic lake in Tasmania. Archie für Hydrobiologie 93, 393-422.

KING, R. D. \& TYLER, P. A. (1983). Sulphide Pool and
Lake Morrison, meromictic lakes of south-west Tasmania. Archic für Hydrobiologie 96, 139-163.

Marchant, H. J. \& Thomas D. P. (1983). Polylysine as an adhesive for the attachment of nanoplankton to substrates for electron microscopy. Journal of $\mathrm{Mi}$. croscopy 131, 127-129.

Parkin, T. B. \& Brock. T. D. (1980). Photosynthetic bacterial production in lakes: the effects of light intensity. Limnology and Oceanography 25, 711-718.

PFenNig. N. (1978). General physiology and ecology of photosynthetic bacteria. In The Photosynthetic Bacteria, pp. 3-18. Edited by R. K. Clayton \& W. R. Sistrom. New York: Plenum Press.

PfenNig, N. (1980). Syntrophic mixed cultures and symbiotic consortia with phototrophic bacteria: a review. In Anaerobes and Anaerobic Infections, pp. 127-131. Edited by G. Gottschalk, N. Pfennig \& H. Werner. Stuttgart. New York: Gustav FischerVerlag.

Stanier, R. Y., Doudoroff, M. \& Adelberg, E. A. (1971). General Microbiology, 3rd edn. London: Macmillan.

Stanier, R. Y., Pfennig, N. \& Trúper, H. G. (1981). Introduction to the phototrophic prokaryotes. In The Prokaryotes, vol. 1, pp. 197-211. Edited by M. P. Starr, H. Stolp, H. G. Trüper, A. Balows \& H. G. Schlegel. Berlin \& New York: Springer-Verlag.

Starr, M. P. \& Schmidt, J. M. (1981). Prokaryote diversity. In The Prokaryotes, vol. 1, pp. 3-42. Edited by M. P. Starr, H. Stolp, H. G. Trüper, A. Balows \& H. G. Schlegel. Berlin \& New York: SpringerVerlag.

TrUPer, H. G. \& Pfennig, N. (1971). Family of phototrophic green sulfur bacteria: Chlorobiaceae Lauterborn: and the taxonomic situation of the consortium-forming species. Request for an opinion. International Journal of Sistematic Bacteriology 21, 8 10.

TrÚPER, H. G. \& PFENNIG, N. (1978). Taxonomy of the Rhodospirillales. In The Photosynthetic Bacteria, pp. 19-27. Edited by R. K. Clayton \& W. R. Sistrom. New York: Plenum Press. 